\title{
Invariant Natural Killer T (iNKT) Cells Prevent Autoimmunity, but Induce Pulmonary Inflammation in Cystic Fibrosis
}

\author{
Nanna Siegmann ${ }^{\mathrm{a}}$ David Worbs ${ }^{\mathrm{a}}$ Frauke Effinger ${ }^{\mathrm{a}}$ Tobias Bormann ${ }^{\mathrm{a}}$ \\ Madlen Gebhardt ${ }^{\mathrm{a}}$ Martina Ulrich ${ }^{\mathrm{a}}$ Fredrik Wermeling ${ }^{\mathrm{b}}$ Eva Müller-Hermelink ${ }^{\mathrm{c}}$ \\ Tilo Biedermannc Mike Tighe ${ }^{d}$ Michael J. Edwards ${ }^{\mathrm{e}}$ Charles Caldwelle \\ Elizabeth Leadbetter ${ }^{d}$ Mikael C. I. Karlsson ${ }^{\dagger}$ Katrin Anne Becker ${ }^{g}$ Erich Gulbins ${ }^{e, g}$ \\ Gerd Döringa
}

\begin{abstract}
anstitute of Medical Microbiology and Hygiene and 'Department of Dermatology, University Hospital, Tübingen, Germany, 'bepartment of Medicine, Karolinska Institutet, Stockholm, Sweden, 'Trudeau Institute, Saranac Lake, NY, USA, eDept. of Surgery, University of Cincinnati, Ohio, USA, 'Department of Microbiology, Tumor and Cell Biology, Karolinska Institutet, Stockholm, Sweden, 9Department of Molecular Biology and Center for Medical Biology, University of Duisburg-Essen, Essen, Germany
\end{abstract}

\author{
Key Words \\ Cystic fibrosis • Inflammation • Lung • Auto-immunity • iNKT-cells
}

\begin{abstract}
Background/Aims: Inflammation is a major and critical component of the lung pathology in the hereditary disease cystic fibrosis. The molecular mechanisms of chronic inflammation in cystic fibrosis require definition. Methods: We used several genetic mouse models to test a role of iNKT cells and ceramide in pulmonary inflammation of cystic fibrosis mice. Inflammation was determined by the pulmonary cytokine profil and the abundance of inflammatory cells in the lung. Results: Here we provide a new concept how inflammation in the lung of individuals with cystic fibrosis is initiated. We show that in cystic fibrosis mice the mutation in the Cftr gene provokes a significant up-regulation of iNKT cells in the lung. Accumulation of iNKT cells serves to control autoimmune disease, which is triggered by a ceramide-mediated induction of cell death in CF organs. Autoimmunity becomes in particular overt in cystic fibrosis mice lacking iNKT cells and although suppression of the autoimmune response by iNKT cells is beneficial, IL-17+ ${ }^{+}$NKT cells attract macrophages and neutrophils to CF lungs resulting in chronic inflammation. Genetic deletion of iNKT cells in cystic fibrosis mice prevents inflammation in CF lungs. Conclusion: Our data demonstrate an important function of iNKT cells in the chronic inflammation affecting cystic fibrosis lungs. iNKT cells suppress the auto-immune response induced by ceramide-mediated death of epithelial cells in CF lungs, but also induce a chronic pulmonary inflammation.


Siegmann et al: iNKT Cells in Cystic Fibrosis

\section{Introduction}

In the hereditary disease cystic fibrosis (CF) [1], mutations in a gene encoding an epithelial cell membrane-located chloride channel, named cystic fibrosis transmembrane conductance regulator (human protein: CFTR, murine protein: Cftr) |2-4], negatively affect the physiology of several organs such as the lungs and intestines [1].

CF lungs are characterized by chronic inflammation that may begin in individuals with $\mathrm{CF}$ as young as 4 weeks of age [5-7]. Bronchiolar lavage samples from CF individuals revealed increased levels of inflammatory cytokines and neutrophils in airways prior to measurable colonization of bacteria [5]. Although infection clearly promotes pulmonary inflammation and CF patients suffer from recurrent lung infections [6], studies on aborted foetuses support the presence of inflammation in CF airways independent of previous infection [7]. Further, the balance between pro-inflammatory and anti-inflammatory cytokines seems to be disturbed in cystic fibrosis lungs as shown in studies on Cftr-deficient mice that showed increased levels of keratinocyte chemoattractant (KC; mouse homolog of interleukin-8) and IL-1 even before infection and decreased levels of anti-inflammatory cytokines, in particular IL-10 [8-14]. The increased release of pro-inflammatory cytokines from Cftr-deficient epithelial cells correlated with a constitutive activation of nuclear factor (NF)- $\kappa B$ [8]. In humans as well as mice, the lung disease is also characterized by large numbers of peribronchial and intra-luminal neutrophils and macrophages that are present independently of infection with pathogenic bacteria [14]. The development of pulmonary inflammation seems to be slightly different in CF-pigs that develop infection first followed by pulmonary inflammation within a few months after birth [15]. At present, the molecular mechanisms driving the chronic inflammation in the CF-lung are unknown.

CFTR-deficiency has been shown to induce an accumulation of ceramide in lungs of CF patients and mice [16-21]. Ceramide is an essential constituent of biological membranes and regulates many physiological cellular responses, including cell death [22-24]. Consequently, in lungs and intestines of people with CF and in CF mice, an increased rate of death of epithelial cells has been observed [16, 25, 26]. Increased cell death may lead to exposure of modified self-antigens [27], triggering an autoreactive B cell-activation [28] and an immune response against antigens derived from dead cells.

Invariant NKT (iNKT) cells are a unique subset of $\mathrm{T}$ cells that express an invariant

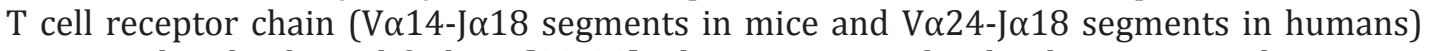
associated with a biased $B$ chain [29-31]. They recognize glycolipid antigens in the context of CD1d, a non-polymorphic MHC class I-like molecule, which is highly conserved through mammalian evolution. iNKT cells have been shown to control autoreactive CD1d-positive B cells in a context with increased cell death using a mouse model for the autoimmune disease systemic lupus erythematosus (SLE) [29, 30, 32]. Reduced numbers of circulating iNKT cells [32] and increased autoantibody levels in patients with SLE support the notion that one of the functions of iNKT cells is to control autoreactive B cell activation triggered by cell death. Since localized spontaneous cell death occur in CF patients we decided to study iNKT cells in Cftr-deficient mice.

Here, we show that in CF mice the deficiency of functional Cftr provokes a significant increase of iNKT cells in the lung. Inhibition of ceramide production, and thereby cell death in CF lungs, abrogated the increase of iNKT cells in the tissue. Genetic deletion of iNKT cells in CF mice resulted in significantly elevated germinal center B cell and autoantibody levels, but on the other hand reduced the number of inflammatory cells, in particular macrophages and neutrophils, in CF lungs. This data indicates that the increased cell death mediated by ceramide in CF lungs results in an activation of iNKT cells that limit the activation of self-reactive B lymphocytes, but drive the recruitment of inflammatory cells to the lung tissue. 
Siegmann et al: iNKT Cells in Cystic Fibrosis

\section{Materials and Methods}

Mice

Cftr ${ }^{\text {tm1Unc }}$-Tg(FABPCFTR)1Jaw/J (abbreviated $C f t r^{\mathrm{K} 0}$ ) mice were bred and housed in the vivarium of the Universities of Duisburg-Essen and Tübingen, Germany. The Cftr ${ }^{\mathrm{KO}}$ mice and the appropriate wild type (WT) strain were backcrossed in a C57BL/6 background. B6.129P2(CF/3)-Cftr ${ }^{\text {TgH(neoim)Hgu }}$ (abbreviated Cftr ${ }^{\mathrm{MHH}}$, syngenic to C57BL/6) were obtained from Burkhard Tümmler (Medizinische Hochschule Hannover, Germany). Wildtype littermates were used as controls. Apart from CF mice, experiments were performed using knockout mice with a deficiency in iNKT cells $\left(J \alpha 18^{-/}\right)$, kindly provided by Stefan Kaufmann (MaxPlanck-Institute for Infection Biology in Berlin, Germany). These mice were originally developed by Masaru Taniguchi to specifically delete the J $\alpha 18$ gene segment and thus prevent expression of invariant V $\alpha 14$ J $\alpha 18$ TCR [31, 32]. Additionally, to study the function of iNKT cells in CF disease, a double knockout mouse model was generated by crossing $C f t r^{\mathrm{MHH}}$ with $J \alpha 18^{-1-}$ mice. The $C f t r^{\mathrm{MHH}}-J \alpha 18^{-1-}$ mice were established as a homozygous line in the vivarium of the University of Tübingen. To study the role of ceramide in $C f t^{K O}$ mice were crossed with acid sphingomyelinase-deficient (gene symbol: Smpd1) mice to obtain $C f t r^{\mathrm{KO}} / \mathrm{Smpd} \mathrm{H}^{\%}$ mice that still express the human CFTR transgene under control of the fatty acid binding promoter. Mice were housed in isolator cages under pathogen-free conditions and routinely investigated for microbial infections by bacterial culturing and serology. All procedures performed on mice were approved by the regional council in Tübingen and conducted according to the German animal protection law.

FACS

We prepared single-cell suspensions of liver, lung, spleen and brain using routine methods. Erythrocytes were lysed and nonspecific binding blocked using anti-CD16/CD32 (BD Biosciences, San Diego, USA). We labeled iNKT cells specifically using PBS57- (an analogue of $\alpha$-GalCer) loaded CD1d tetramer, kindly provided by the NIH Tetramer Core Facility of Emory University, Atlanta, USA, together with anti-TCR $\beta$ (BD Biosciences). Expression of activation and proliferation markers on iNKT cells was investigated using antibodies against CD69 and Ki-67 (both from BD Biosciences). Additionally we analyzed GC B cells using specific monoclonal antibodies against B220, CD95 and GL7 (BD Biosciences). For intracellular cytokine staining, single cell suspensions were cultured in complete medium for $5 \mathrm{~h}$ in the presence of PMA (10 ng/ $\mathrm{ml}$ ), Ionomycin (250 ng/ml; both from Sigma-Aldrich, Deisenhofen, Germany) and $2 \mu \mathrm{l}$ of Golgiplug (BD Biosciences). Extracellular proteins were then labelled, followed by fixation and permeabilization (Cytofix/ Cytoperm Plus Kit, BD Biosciences). Intracellular IFN $\gamma$ and IL-17 were labelled and samples were analyzed on a FACS LSRII (BD, San Jose, USA), using the FACSDiva Software.

\section{ELISA}

Autoantibodies against dsDNA were investigated in serum and bronchoalveolar lavages of mouse strains using a previously published assay ${ }^{29}$. Furthermore, IFN- $\gamma$ and IL-17 levels in iNKT cells of mouse lung tissues were assessed using Quantikine ELISA Kits (R\&D, Minneapolis, USA) after stimulation with $1 \mu \mathrm{l} \alpha$-GalCer (KRN7000 $1 \mathrm{mg} / \mathrm{ml}$; Avanti Polar Lipids, Alabaster, USA). BAFF levels were determined by a specific ELISA (Quantikine ELISA murine BAFF; R\&D) in serum specimens of mouse strains.

\section{Immunohistology}

For determination of neutrophil and macrophage numbers in mouse lung tissues, $5 \mu \mathrm{m}$ lung tissue sections were fixed on glass slides with acetone, rinsed with PBS-Tween $(0.1 \%)$ and pre-incubated with normal goat serum, diluted 1:10 in PBS-Tween (0.1\%). The sections were then incubated with monoclonal rat antibodies to mouse macrophages (CD68, Acris, Herford, Germany) or to neutrophils (clone 7/4, Acris), diluted 1:50 in PBS-Tween (0.1\%), for $1 \mathrm{~h}$ at room temperature. After washing with PBS-Tween (0.1\%), the sections were incubated with a 1:100 dilution of Cy2-conjugated goat anti-rat IgG (Dianova, Hamburg, Germany) for $1 \mathrm{~h}$ at room temperature, followed by three washing steps with PBS-Tween (0.1\%). Additionally, cell nuclei were stained with DAPI (1 mg/ml; Sigma-Aldrich, Hamburg, Germany), diluted 1:500 in PBSTween $(0.1 \%)$ for $5 \mathrm{~min}$. The samples were washed and covered with fluorescence mounting medium. For quantitative determination, four sections of every lung lobe were examined and fluorescently labeled cells were counted in an image area of $340 \times 270 \mu^{2}$ (magnification: x400) with an Axioplan microscope (Zeiss, Jena, Germany). 
To visualize B and iNKT cells in mouse spleens and lungs confocal microscopy was used. Therefore fresh mouse lungs were filled with liquid 5\% agarose just before harvest. Both mouse lungs and spleens were harvested and immediately placed in 5\% agarose blocks for sectioning. Tissue was cut into $200 \mu \mathrm{m}$ thick sections using a Leica VT1000S vibrating microtome. Tissue antibody staining was performed on ice for 60 minutes with the exception of $\alpha$-GalCer CD1d tetramer labeling which was performed at room temperature for $30 \mathrm{~min}$ prior to staining with other antibodies on ice and analysis by confocal microscopy (Leica TCS SP5). Surface antibody staining included B220-PacBlue, GL7-FITC or -APC and $\alpha$-GalCer-loaded CD1d tetramer (provided by NIH Tetramer Core Facility). Sections were blocked in PBS plus 2\% BSA and 5\% normal mouse serum for 60 min prior to specific antibody staining.

Additionally, we performed the TUNEL assay in mouse lung tissues using the In Situ Cell Death Detection Kit from Roche (Mannheim, Germany).

\section{Adoptive transfer of iNKT cells}

For adoptive iNKT cell transfer, untouched iNKT cells were enriched from liver and spleen of $V \alpha 14$ $\mathrm{C} \alpha{ }^{/-}$mice by magnetic activated cell sorting using the MidiMACS Separator (Miltenyi Biotech, Bergisch Gladbach, Germany). Negative selection was performed by depletion of B220 ${ }^{+}, \mathrm{CD}^{+}, \mathrm{CD}_{11 \mathrm{~b}^{+}}$and $\mathrm{CD} 11 \mathrm{c}^{+}$ cells according to manufacturer's instructions. This isolation technique yields mainly iNKT cells and some $\mathrm{CD}^{+} \mathrm{T}$ cells. Approximately $2 \times 10^{6}$ untouched viable iNKT cells from $\mathrm{V} \alpha 14-\mathrm{C} \alpha^{1-}$ mice were injected i.v. in one recipient $C f t \mathrm{HH}_{-}^{\mathrm{MH}} \alpha 18^{-/-}$mouse. In a first experiment $2 \mathrm{Cft} \mathrm{r}^{\mathrm{MHH}}-J \alpha 18^{-/-}$mice received injections at day 0,7 and 14. In a second experiment $3 \mathrm{Cftr} \mathrm{MH}_{-} J \alpha 18^{-/-}$mice received a single injection of enriched iNKT cells. One week after the last injection, $C f \mathrm{tr}^{\mathrm{MHH}}-\mathrm{J} \alpha 18^{-/-}$mice were sacrificed and cells from liver, lung and spleen were isolated and stained for FACS analysis. Animals injected with PBS were used as negative controls.

\section{Statistical analysis}

Data, which were normally distributed, were analyzed using the Student's t test or one-way Anova followed by Bonferroni's test. Results with inhomogeneous variances in the Student's t test were analyzed using the non-parametric Mann-Whitney test or Kruskal-Wallis test followed by Dunn's multiple comparison test. A p value of 0.05 or less was considered significant.

\section{Results}

Inducible NKT cells are elevated in cystic fibrosis mice

Since a link has been established between cell death, iNKT cells and autoimmune disease [29-31], we tested how iNKT cells respond to increased apoptosis and cell death in CF mice. We employed two CF mouse strains (on C57BL/6 background) and the appropriate wildtype littermates. Cftr-KO carry a null mutation caused by introducing a stop codon in exon 10 and thereby leading to disruption of the $c f t r$ gene [33]. In addition, these mice express human CFTR in the gut epithelium under control of a fatty acid binding protein (FABP) promoter, which prevents acute intestinal obstruction. Thus, these mice lack Cftr in all tissues except the intestine. B6.129P2(CF/3)-Cftr ${ }^{\text {TgH(neoim)Hgu }}$ (abbreviated Cftr ${ }^{\mathrm{MHH}}$, syngenic to C57BL/6) were generated by insertional mutagenesis targeted to exon 10 of the $c f t r$ gene and backcrossing to a C57BL/6 inbred strain to obtain congenic mice [34]. These mice have a residual activity of Cftr in the gut allowing to feed them with a normal diet. All mice were housed in a clean environment devoid of microbial infections. In both CF mouse strains carrying the mutations Cftrtm1Unc-Tg(FABPCFTR)1Jaw/J (abbreviated Cftr ${ }^{\mathrm{KO}}$ ) and B6.129P2(CF/3)Cftr ${ }^{\text {TgH(nеоіт)Hgu }}$ (abbreviated Cftr ${ }^{\mathrm{MHH}}$ ), increased iNKT cell numbers in the lung compared to controls, were observed by FACS analysis using a mouse specific glycolipid-loaded tetramer allowing to specifically detect iNKT cells (Fig. 1a-c). As specificity controls, we used $C f^{\mathrm{MHH}}$ mice crossed with $J \alpha 18^{-/}$mice, lacking the J $\alpha 18$ segment used by the semi-invariant iNKT cell receptor [32] and, therefore, $\mathrm{Cftr} \mathrm{MHH}_{-\mathrm{J}} \mathrm{J} 18^{-/}$mice do not produce iNKT cells (Fig. 1c). The link between $C f t r$-deficiency and iNKT cell accumulation is further supported by the finding that $C f t r$-deficient mice also showed increased iNKT numbers in splenocytes that express Cftr, while they did not accumulate iNKT cells in the liver, where Cftr is not expressed (Fig. 
Fig. 1. iNKT cells are elevated in cystic fibrosis tissues. (a) Increased iNKT cell numbers in lung tissue of $\mathrm{Cftr}^{\mathrm{KO}}$ and $C f t r^{\mathrm{MHH}}$ mice compared to control animals. Lung lymphocytes of Cftr ${ }^{\mathrm{KO}}, C f t r^{\mathrm{MHH}}$ mice and the respective wild type littermates were labeled with anti-TCR $\beta$ and the CD1d tetramer and analyzed by flow cytometry. Representative flow cytometry data are shown. The percentage of iNKT cells of all T lymphocytes, gated for TCR $\beta$ and CD1d tetramer staining, is indicated as mean of 10 animals. (b) iNKT cell numbers are increased in lungs, but not in livers of $C f t r^{\mathrm{KO}}$ mice. iNKT cells were analyzed as in (a). Values represent individual mice $(n=9$ 11) and the mean is given by the horizontal line (**: p < 0.01, ***: $\mathrm{p}<0.001$, t-test). (c) iNKT cell numbers are increased in lungs and spleens of 6-10 Cftr ${ }^{\mathrm{MHH}}$ mice. iNKT cells were analyzed as in (a) $\left({ }^{*}: \mathrm{p}<0.05,{ }^{* *}: \mathrm{p}<0.01, \mathrm{t}\right.$-test). (d) Lymphocytes from lungs of $C f r^{\mathrm{KO}}$ and $C f t^{\mathrm{MHH}}$ mice were isolated and analyzed as in panel a. Values represent the absolute number of iNKT cells per organ from 12-15 mice and the mean is given by the horizontal line (**: $\mathrm{p}<0.01$, ***: $\mathrm{p}$ $<0.001$, t-test). (e) Lymphocytes from lung and liver of $C f \mathrm{fr}^{\mathrm{KO}}$ mice and the respective wild type mice, aged 4 to 40 weeks, were isolated and iNKT cells analyzed. Values of 4 mice are expressed as mean $\pm \mathrm{SD}$ (***: p < 0.001, t- test). (f) Lymphocytes were isolated from the indicated organs of $\mathrm{Cftr}^{\mathrm{MHH}}$ and wild type (B6) mice and iNKT cells analyzed. Values represent individual mice $(n=5-10)$ and the mean is given by the horizontal

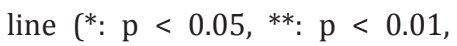
t-test). (g) iNKT cells upregulate

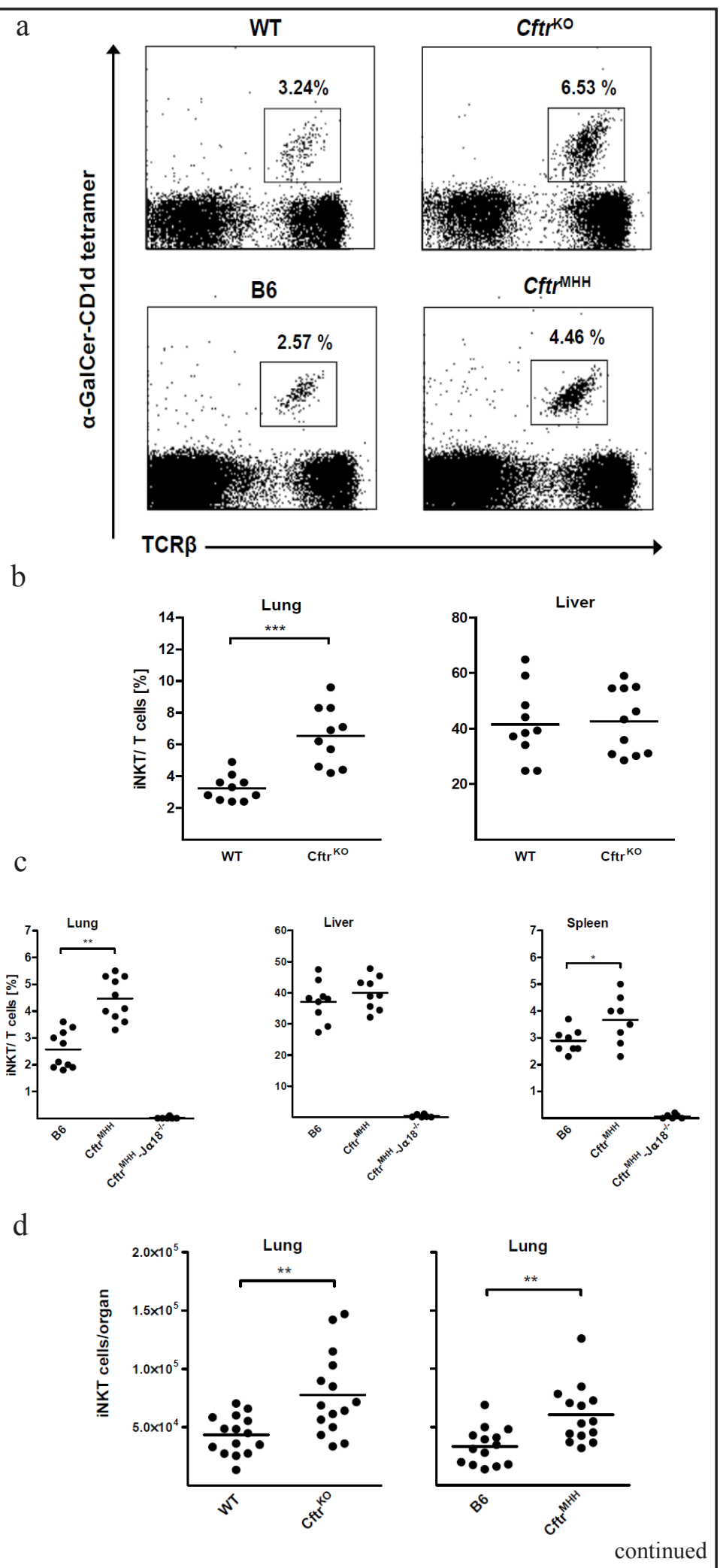

activation and proliferation markers in spleen and lung of $C f t r^{\mathrm{MHH}}$ mice. Lymphocytes were isolated from spleen and lung of $C f \mathrm{fr}^{\mathrm{MHH}}$ mice and frequencies of iNKT cells expressing CD69 or Ki-67 were determined by FACS and calculated as percentage of the total CD1d tetramer ${ }^{+}$cell population. Values represent individual mice $(n=5-6)$ and the mean is given by the horizontal line $\left(*: p<0.05 ; * *: p<0.01{ }^{* * *}: p<0.001, t\right.$-test). 


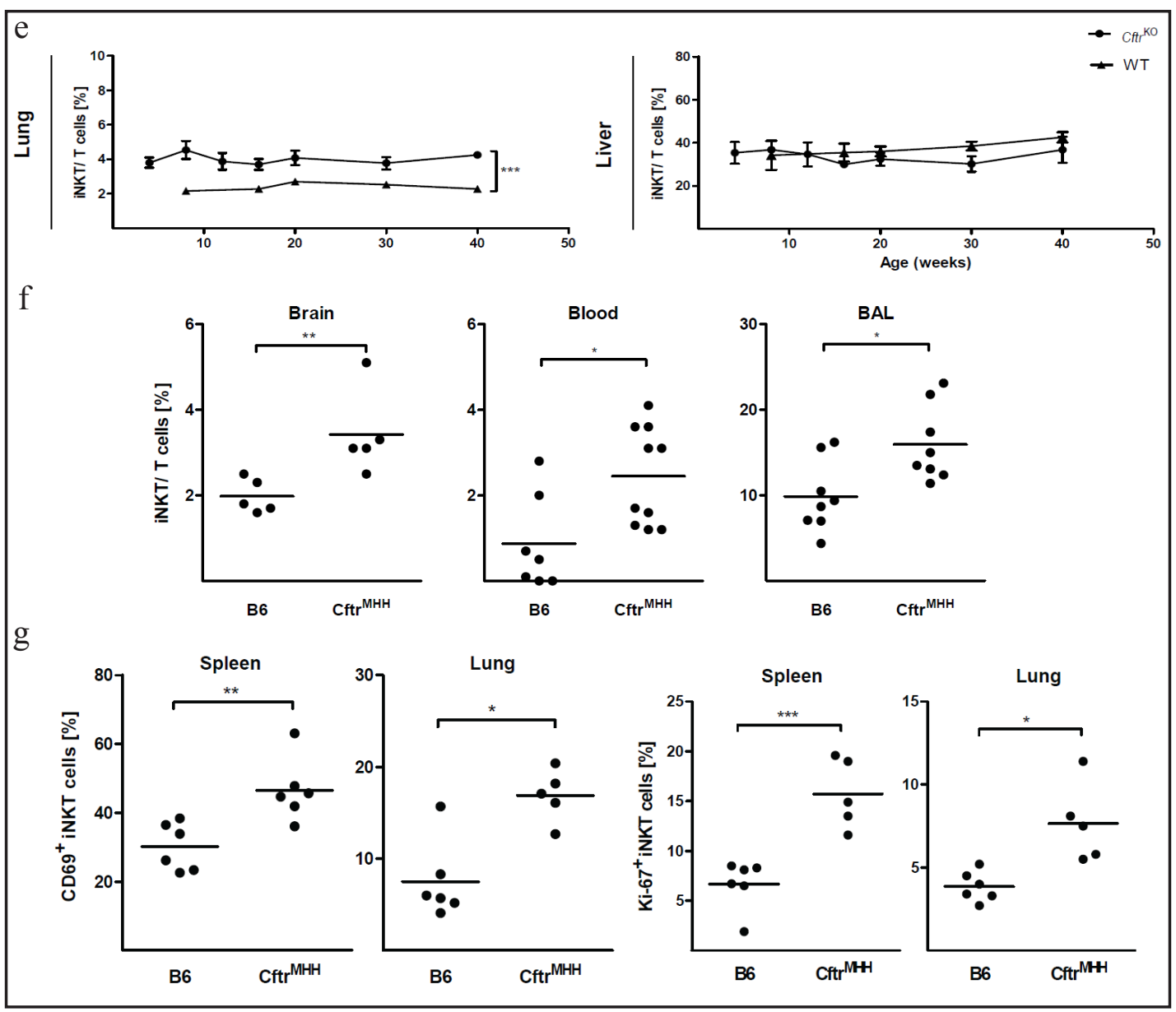

1a-c) [35]. This indicates that iNKT cells predominantly accumulate in tissues deficient for Cftr such as lung and spleen. The absolute number of iNKT cells in lungs of both CF-mouse strains is shown in Fig. 1d, demonstrating that the percentage of the expanded iNKT cell population is not caused by a decreased T cell population. Because the deficiency of Cftr in $\mathrm{CF}$ is present already after birth, we sought to know the time point when iNKT cells increase over controls. iNKT cell numbers rapidly increased after birth in lung tissues of $C f t^{\mathrm{KO}}$ mice (Fig. 1e). To further demonstrate that accumulation of iNKT cells in Cftr-deficient mice is a consequence of $C f t r$-deficiency and not caused by any microbial infection, we determined iNKT cell numbers also in brain tissue of $C f t r^{\mathrm{MHH}}$ mice. Cftr is expressed in the brain and if Cftr-deficiency results in iNKT accumulation, this process should also occur in the brain of CF mice. An increased rate of iNKT cells was observed in the brain of CF mice compared to brain from respective control mice (Fig. 1f). Similarly, in blood and bronchoalveolar lavage (BAL) fluids iNKT cell numbers were elevated in $C f t r^{\mathrm{MHH}}$ mice versus wild type mice (Fig. 1f). iNKT cells isolated from lungs and spleens of $C f t r^{\mathrm{MHH}}$ mice showed an activated phenotype compared to the respective wild type mouse strain as reflected by increased expression of CD69, a marker of activated T-lymphocytes and NK cells, and Ki-67, a widely used marker of proliferation (Fig. 1g).

Collectively, these data indicate an accumulation of iNKT cells in the lung of CF mice.

\section{iNKT cells control autoantibody formation in CF mice}

The increased apoptosis in Cftr lungs and intestines [16, 25, 26] might result in an autoimmune reaction with the formation of autoantibodies, which has been previously described in CF patients [36] and the accumulation of iNKT cells in the tissues could be the attempt of the organism to prevent this autoimmune reaction. To test this hypothesis, 
Fig. 2. Elevated iNKT cell numbers in cystic fibrosis mice control autoantibody titers against apoptotic cell antigens. Serum autoantibody levels against dsDNA are increased in $\mathrm{Cftr}^{\mathrm{MHH}}-\mathrm{J} \alpha 18^{-/}$ mice. Serum was collected from $10 \mathrm{~B} 6, \mathrm{Cftr}^{\mathrm{\textrm {HH }}}, \mathrm{Cft} \mathrm{rHH}^{\mathrm{MH}}$ $J \alpha 18^{-/}$and $J \alpha 18^{-/-}$mice and analyzed for $\operatorname{IgG}_{1}, \quad \operatorname{IgG}_{2 \mathrm{~b}}$, $\operatorname{IgG}_{2 c^{\prime}} \operatorname{IgG}_{3}$ and IgM antibodies against dsDNA by ELISA. Values represent individual mice and the mean is given by the horizontal line $\left(^{*}: \mathrm{p}<0.05,{ }^{* *}: \mathrm{p}<0.01,{ }^{* * *}\right.$ : $\mathrm{p}<0.001$, Kruskal-Wallis test).
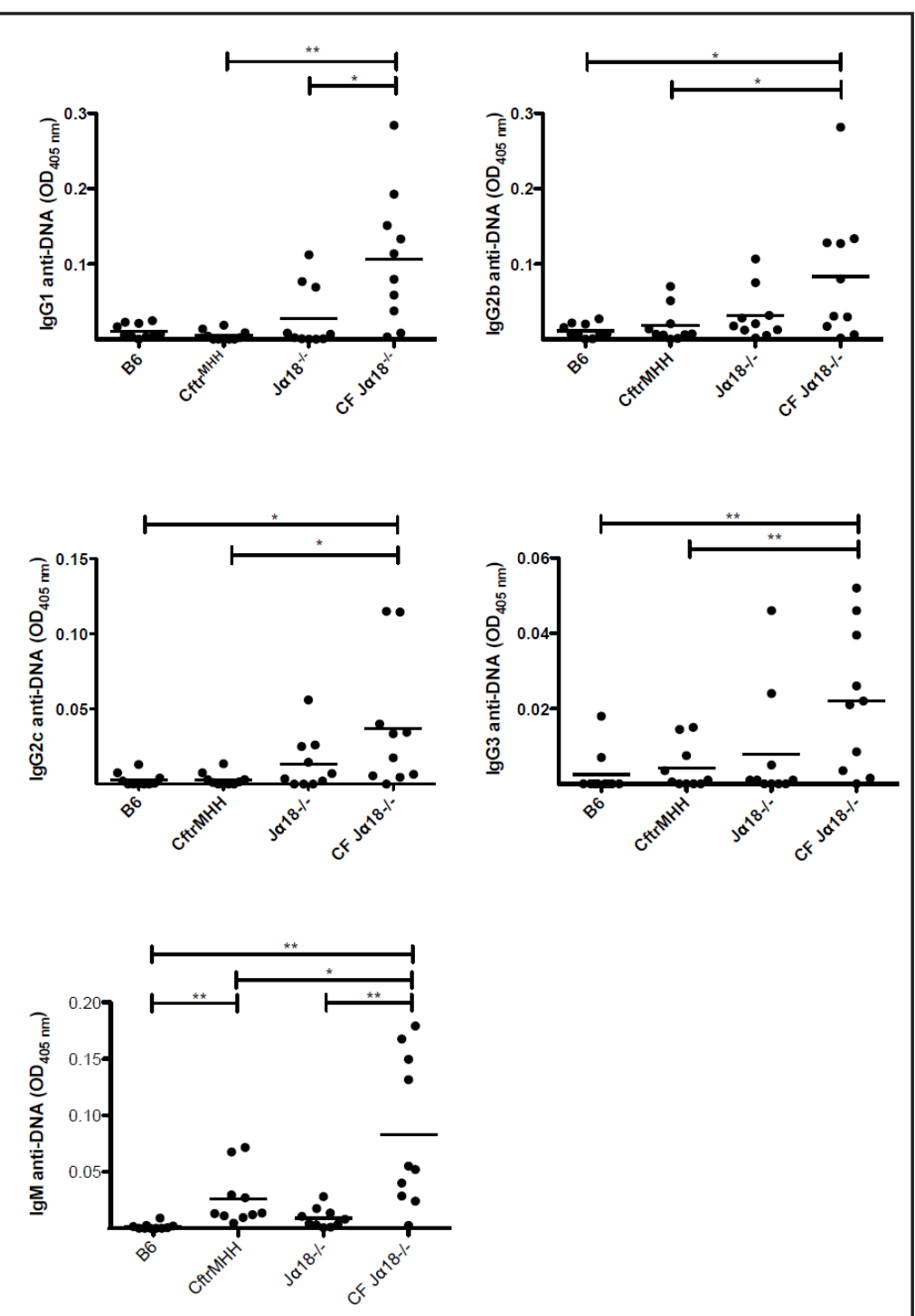

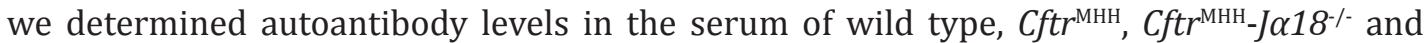
$\mathrm{J} \alpha 18^{-\%}$ mice. The data revealed significantly increased serum IgG1 and IgM autoantibody titers against double stranded (ds) DNA, which is presumably released from dying cells during an autoimmune disorder, in $\mathrm{Cftr}^{\mathrm{MHH}}-\mathrm{J} \alpha 18^{-/-}$compared to $\mathrm{Cft} \mathrm{CHH}^{\mathrm{MH}}$ or $\mathrm{J} \alpha 18^{-/}$mice (Fig. 2a). We also observed increased levels of IgG2a, IgG2c and IgG3 in $\mathrm{Cftr}^{\mathrm{MHH}}-J \alpha 18^{-{ }^{-}}$compared to $C \mathrm{ftr}^{\mathrm{MHH}}$ mice, which did, however, not reach statistical significance when compared to $J \alpha 18^{-/}$mice.

These findings show that CF mice partly or completely control the expression of autoantibodies against dsDNA and possibly other autoantigens by recruiting elevated numbers of iNKT cells to tissues affected by mutated $C f t r$, suggesting increased apoptosis as causative mechanism.

Increased iNKT cells in cystic fibrosis mice prevent up-regulation of autoreactive germinal center $C D 1 d^{+} B$ cells

Since iNKT cells prevent autoreactive B cell entry into germinal centers [29], we hypothesized that $C \mathrm{ftr}^{\mathrm{MHH}}$ mice express lower levels of germinal center phenotype B cells than Cftr ${ }^{\mathrm{MHH}}-J \alpha 18^{\%}$ mice. In accordance, FACS analysis of $\mathrm{GL} 7{ }^{\mathrm{hi}} \mathrm{CD} 95^{\mathrm{hi}} \mathrm{B}$ cells revealed significant higher concentrations in spleen and lung of $C \mathrm{ftr}^{\mathrm{MHH}}-J \alpha 18^{-/-}$mice compared to the other mouse 
Fig. 3. Increased iNKT cell numbers in cystic fibrosis mice prevent up-regulation of autoreactive germinal center $\quad$ CD1 $^{+}$ B cells. (a) Increased numbers of germinal center $B$ cells are present in spleens and lungs of $\mathrm{Cftr}^{\mathrm{MHH}}$ Ja18 ${ }^{-} \quad$ mice. Isolated lymphocytes of B6, Cftr ${ }^{\mathrm{MH}}, \quad C f t r^{\mathrm{MHH}}$ Ja18 $\%$ and Ja18\% mice were labelled with anti-B220, anti-GL7 and anti-CD95 and analyzed by FACS. (A) Representative FACS plots showing GL7 and CD95 gating of viable B220+ lymphocytes in the spleen. (B) Quantification of GC B cells in spleen and lung of the different mouse strains. All mice were 30 weeks old. Values represent means (A) and individual mice and means (B) of 6-10 mice (***: $\mathrm{p}<0.001$, ****: $\mathrm{p}<0.0001$, ANOVA).

The B-cell activation factor from the tumor

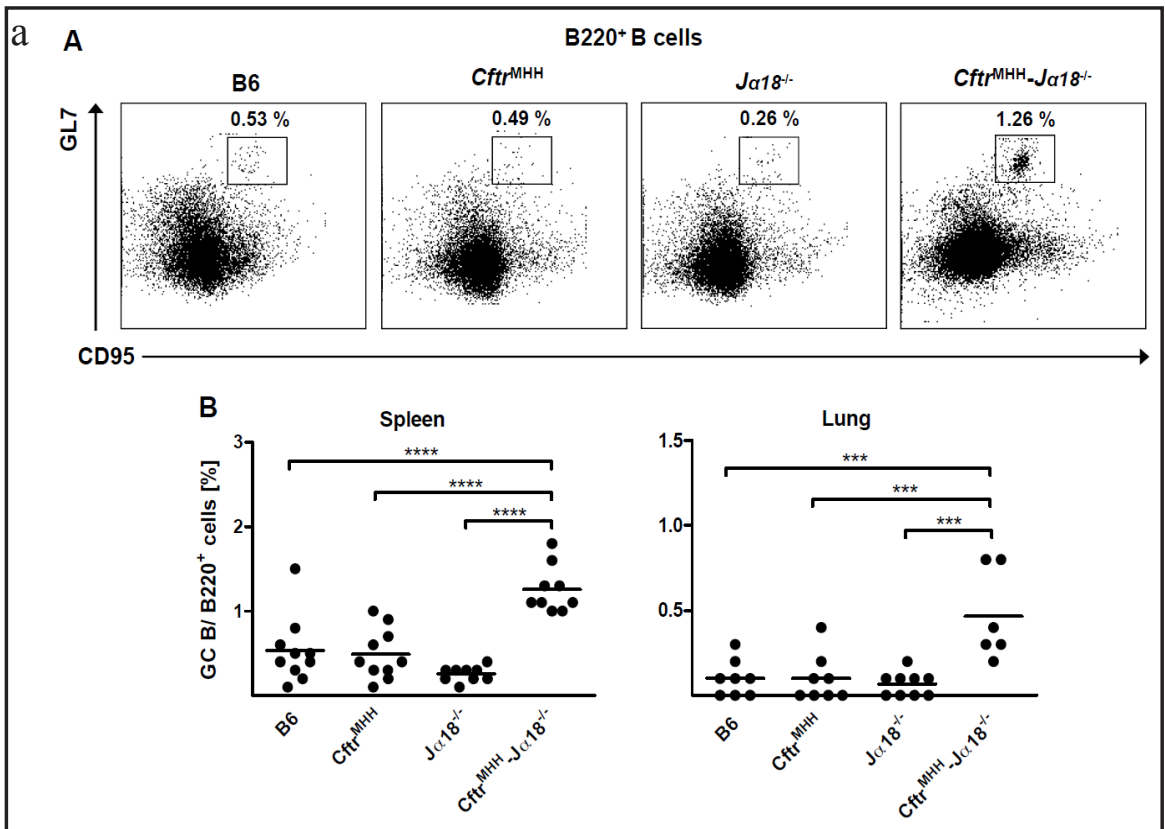

$\mathrm{b}$
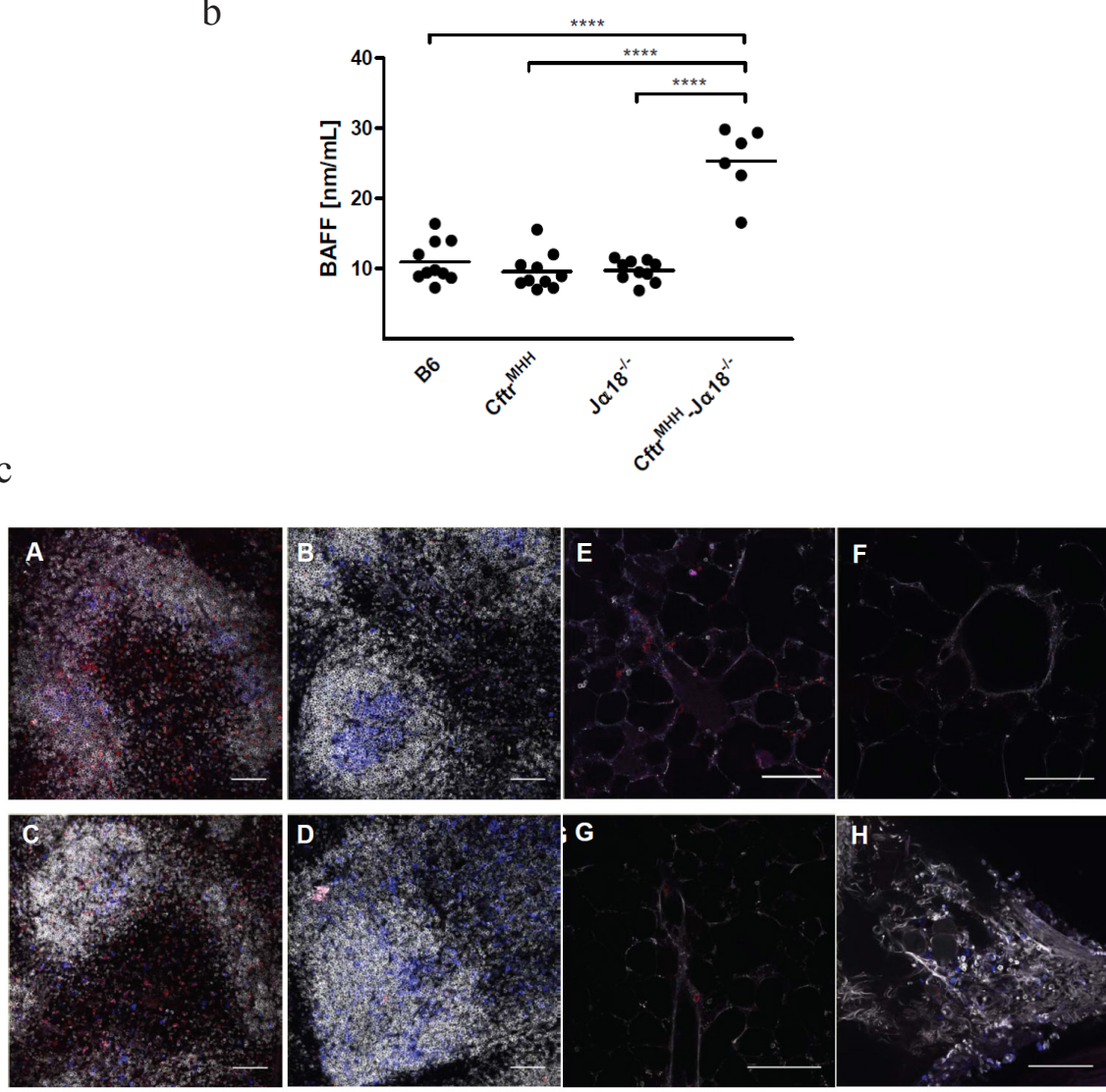

necrosisfactorfamily (BAFF) isincreasedin $C f t^{\mathrm{MHH}}-J \alpha 18^{-/}$mice. BAFFlevelswere determined by ELISAin serum samples of $C f t r^{\mathrm{MHH}}, C f t^{\mathrm{MHH}}-J \alpha 18^{-\%}, \mathrm{~B} 6$ and $J \alpha 18^{-/}$mice $(\mathrm{n}=6-10)$. Values represent individual mice and the mean is given by the horizontal line $(* * * *: p<0.0001$, ANOVA). (c) Confocal images of mouse spleens

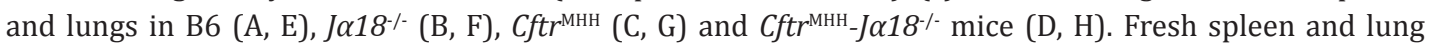
sections were labeled with anti-B220 (white), GL7 (blue), and $\alpha$-GalCer-loaded CD1d tetramer (red). 


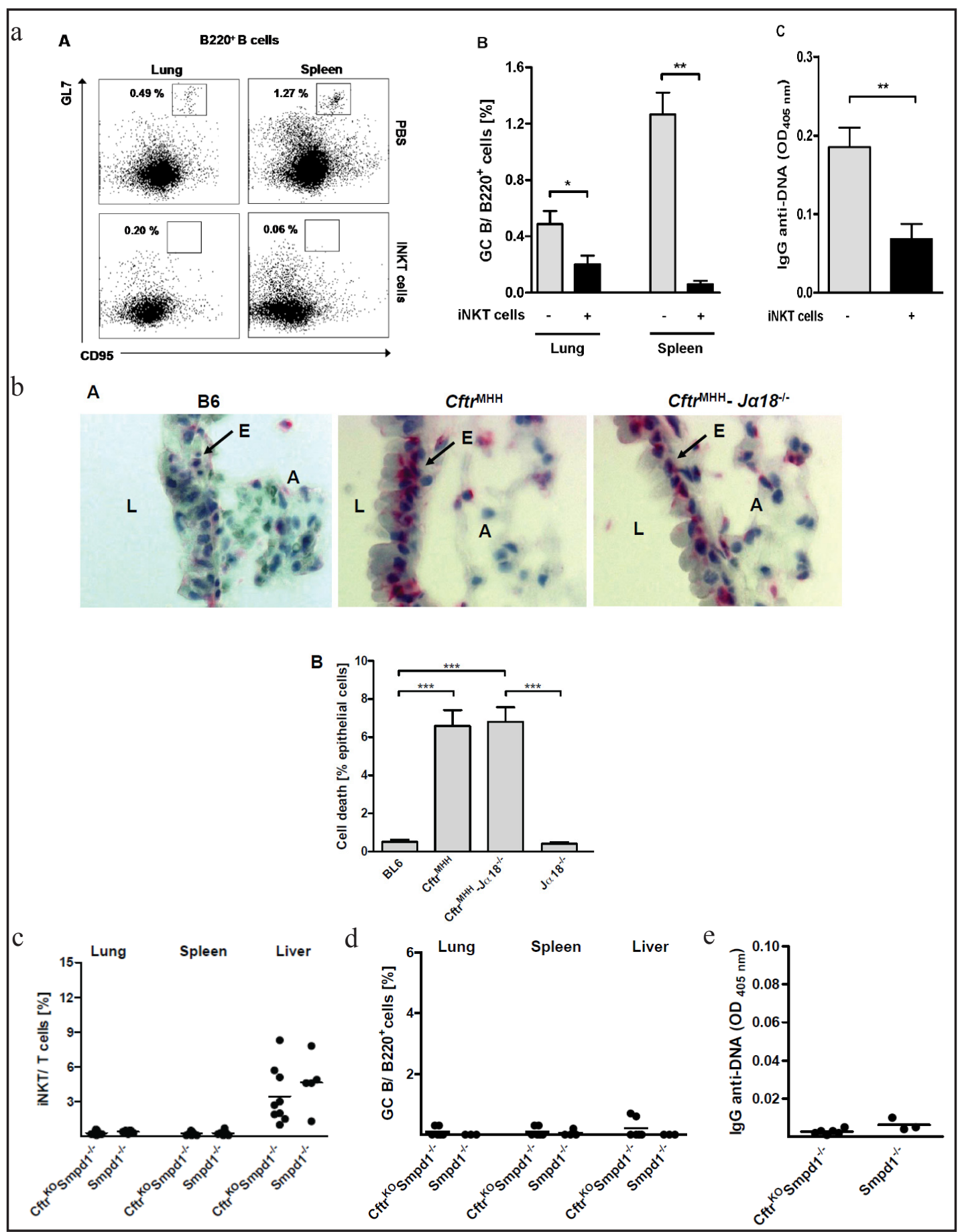

Fig. 4. Ceramide-induced cell death induces an iNKT cell-controlled autoreactive germinal center B cell response in cystic fibrosis mice. (a) Adoptive transfer of iNKT cells reduces numbers of GC B cells and autoantibodies in $C f r^{\mathrm{MHH}}-J \alpha 18^{-/-}$mice. Isolated lymphocytes of five $C f t r^{\mathrm{MHH}}-J \alpha 18^{-/-}$mice which received iNKT cells were labelled with anti-B220, anti-GL7 and anti-CD95 and analyzed by FACS. Control animals received phosphate buffered saline. (A) Representative FACS plots showing GL7 and CD95 gating of viable B220+ lymphocytes in lung and spleen of control (top row) and with iNKT cell injected mice (bottom row). (B) Quantification of GC B cells in lung and spleen. (C) IgG anti-DNA response measured by ELISA. Data are representative of two independent experiments. Values represent means (A) or mean \pm SEM (B, C; $n=3-8)$ $\left(^{*}: \mathrm{p}<0.05\right.$; **: $\mathrm{p}<0.01$, Mann-Whitney test). (b) TUNEL staining of lung tissue in B6, Cftr ${ }^{\mathrm{MHH}}$ and Cftr ${ }^{\mathrm{MH}}$ J $\alpha 18^{-/}$mice (A). Dead cells (red-stained nuclei) were dispersed in the mucosa of large and medium-sized 
Siegmann et al: iNKT Cells in Cystic Fibrosis

bronchi in $C f t r^{\mathrm{MHH}}$ and $C f t^{\mathrm{MHH}}-J \alpha 18^{\%}$ mice. A, alveolar tissue; E, epithelial cell layer; L, bronchial lumen. Original magnification: x400. B, Quantification of dead epithelial cells in different mouse strains. Results are expressed as mean \pm SEM of cells counted in 10 bronchi per mouse of 5 mice per group ( ${ }^{* * *}: \mathrm{p}<0.001$, ANOVA). (c, d) $\mathrm{Cftr}^{\mathrm{KO}} \mathrm{Smpd1 \%}$ mice exhibit reduced iNKT cell numbers and decreased germinal center B cell numbers. Lymphocytes were isolated from lung, spleen and liver of $C \mathrm{ftr}^{\mathrm{KO}} \mathrm{Smpd1}{ }^{\%}$ and $\mathrm{Smpd1}$. mice and iNKT and B cells were analyzed as in Fig. 1a and 2a (Kruskal-Wallis test). (e) Serum IgG anti-DNA levels of $C f r^{\mathrm{KO}} \mathrm{Smpd1} 1^{\%}$ mice were measured by ELISA. Values represent individual mice $(\mathrm{n}=3-9)$ and the mean is given by the horizontal line (Mann-Whitney test).

strains (Fig. 3a). Consistent with this data, the B-cell activation factor from the tumor necrosis factor family (BAFF) [37], a factor that is mainly produced by neutrophils, monocytes and macrophages and is important for B cell survival, was increased in serum samples of $C \mathrm{ftr}^{\mathrm{MHH}}$ $\mathrm{J} \alpha 18^{-\%}$ mice, but not in the other mouse strains (Fig. 3b). Confocal images of spleens revealed

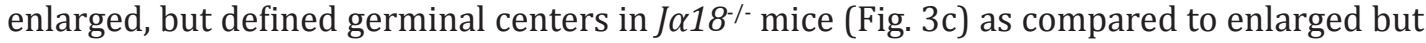
diffuse germinal centers in $\mathrm{Cftr}^{\mathrm{MHH}}-J \alpha 18^{-/-}$(Fig. 3c) and normal small, rare germinal centers in unmanipulated wild type and $C \mathrm{ftr}^{\mathrm{MHH}}$ mice (Fig. $3 \mathrm{c}$ ). This was also reflected in the confocal images of lung tissues, in which we found more cellular infiltrates of germinal center B cells among other cells in $\mathrm{Cftr} \mathrm{MHH}_{-} \mathrm{J} \alpha 18^{-/-}$mice (Fig. 3c) as compared to relatively acellular lungs in wild type, $J \alpha 18^{\%}$ and $\mathrm{CftrMHH}$ mice (Fig. 3c).

Next, we assessed whether adoptively transferred iNKT cells into CftrMHH-J $\alpha 18^{\%}$ mice reduce markers of autoimmunity. The number of germinal center B cells was significantly reduced in lung and spleen of CftrMHH-J $\alpha 18^{\%}$ mice treated with iNKT cells compared to untreated controls (Fig. 4a). Furthermore, serum IgG anti-DNA levels were significantly reduced in CftrMHH-J $\alpha 18^{\%}$ mice after iNKT cell transfer compared to controls (Fig. 4a). These findings demonstrate that repopulation of iNKT cells reduces autoreactive B cell parameters, such as numbers of germinal center B cells and serum autoantibody levels and support previous results of an iNKT cell transfer in a mouse model of SLE [29].

To gain insight into the mechanisms, how Cftr-deficiency mediates an autoimmune response, we used $C f t^{\mathrm{KO}} S m p d 1 \%$ mice. Heterozygosity of the acid sphingomyelinase in $C f t r^{\mathrm{KO}}$ mice normalizes ceramide levels in the lung, trachea and intestine of CF mice and thereby normalizes cell death in CF airways [16]. Our data confirm this previously published notion [16] and show increased cell death in CF and $C f t r^{\mathrm{MHH}}-J \alpha 18^{-/-}$mice, which was normalized by deficiency of the acid sphingomyelinase in $\mathrm{Cftr}^{\mathrm{KO}} \mathrm{Smpd1} 1 \%$ mice (Fig. 4b). Consistent with the induction of iNKT cells by ceramide-mediated cell death, the comparison of $C f \operatorname{tr}^{\mathrm{KO}} \mathrm{Smpd} 1 \%$ mice with CF-mice revealed very low iNKT cell levels in the lung (Fig. 4c and Fig. 1 b), low levels of germinal center B cells (Fig. 4d and Fig. 3a), and low serum autoantibody titers (Fig. 4e and Fig. 2a). The values of these parameters in $C f{ }^{\mathrm{KO}} S m p d 1^{-}$mice did not differ from that in wildtype (Figs. 1b, 2a and 3a) or Smpd1\% mice (Figs. 4c-e), demonstrating that the autoreactive germinal center B cell response in CF mice is a consequence of ceramide accumulation in CF tissues and possibly ceramide-induced cell death caused by the Cftr mutation.

iNKT cells recruit macrophages and neutrophils to lung tissues of cystic fibrosis deficient mice

iNKT cells have pleiotropic functions in innate immunity and upon recognition of endogenous ligands may produce massive amounts of cytokines such as IFN- $\gamma$, TNF- $\alpha$ or IL-17 [38, 39]. IL-17 is a strong chemoattractant for neutrophils, which accumulate in lung tissues of uninfected CF mice. We therefore sought to characterize the phenotype of the increased iNKT cell population in different organs of $C \mathrm{ftr}^{\mathrm{MHH}}$ mice by ELISA and FACS. To this end, iNKT cells were obtained from lungs and spleens of $C f t r^{\mathrm{MHH}}$ mice or wildtype mice using tetramer technology, stimulated ex vivo with PMA/Ionomycin and the percentage of iNKT cells producing IFN- $\gamma$ or IL-17 was determined. The results show that iNKT cells from $\mathrm{CF}$ mice produced significantly less IFN- $\gamma$ than cells obtained from wild type mice (Fig. 5a), 
Fig. 5. iNKT cells recruit macrophages and neutrophils to lung tissues of cystic fibrosis deficient mice and alter their cytokine profile. (a) IFN- $\gamma$ and IL-17 FACS staining of splenic and lung iNKT cells after ex vivo stimulation with PMA/ I on o mycin / Golgiplug. The lower panel shows IFN- $\gamma$ and IL-17 concentrations in super- $b$
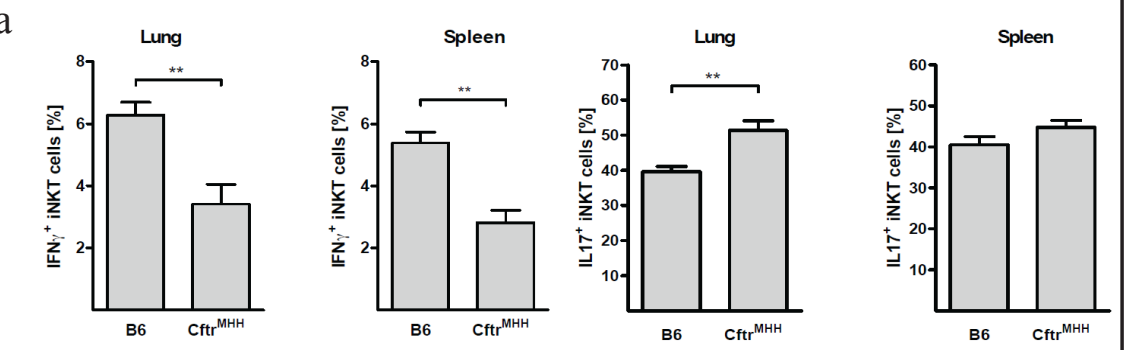

natants of lung lymphocytes of Cftr ${ }^{\mathrm{MHH}}$ and B6 mice stimulated with $\alpha$-GalCer and measured by ELISA. Values represent
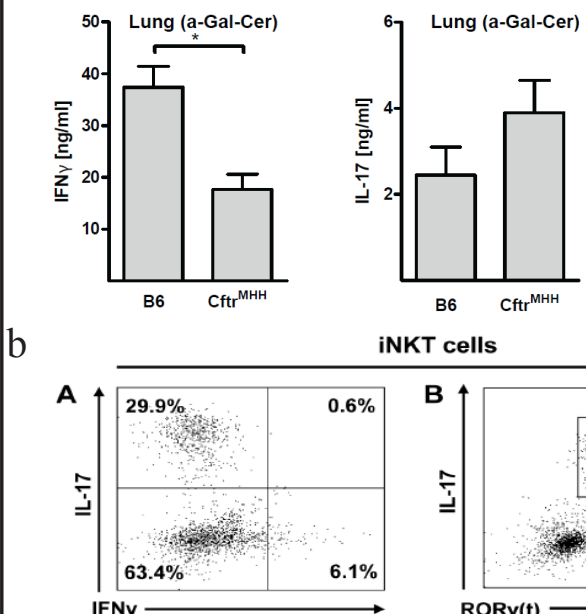

iNKT cells

means of 6-9 mice \pm SEM.

(*: $\mathrm{p}<0.05$, **: $\mathrm{p}<0.01$, t-test). Data are representative of 3 independent experiments. (b) Phenotype of iNKT cells from lungs of Cftr ${ }^{\mathrm{MHH}}$ mice. Percentage of iNKT cells, expressing IL17 and IFN- $\gamma(\mathrm{A})$, IL-17 and ROR- $\gamma \mathrm{t}$ (B), and ROR- $\gamma \mathrm{t}^{+}$ iNKT cells expressing IL-17 and CD4 (C). (c) Lung tissue of B6, Cftr ${ }^{\mathrm{MHH}}$ and $C f \mathrm{fr}^{\mathrm{MHH}}$ $J \alpha 18^{-/}$mice was stained with DAPI (blue) and specific antibodies against macrophages (A) (green) and neutrophils (B) (green). A, alveolar tissue; $\mathrm{B}$, bronchial lumen; E, epithelial cell layer. Original magnification: $\mathrm{x} 400$. C, macrophage counts; $\mathrm{D}$, neutrophil counts in the different mouse strains. Values represent individual mice ( $n=5)$ and the mean is given by the horizontal line (***: $\mathrm{p}<0.001$, ANOVA).
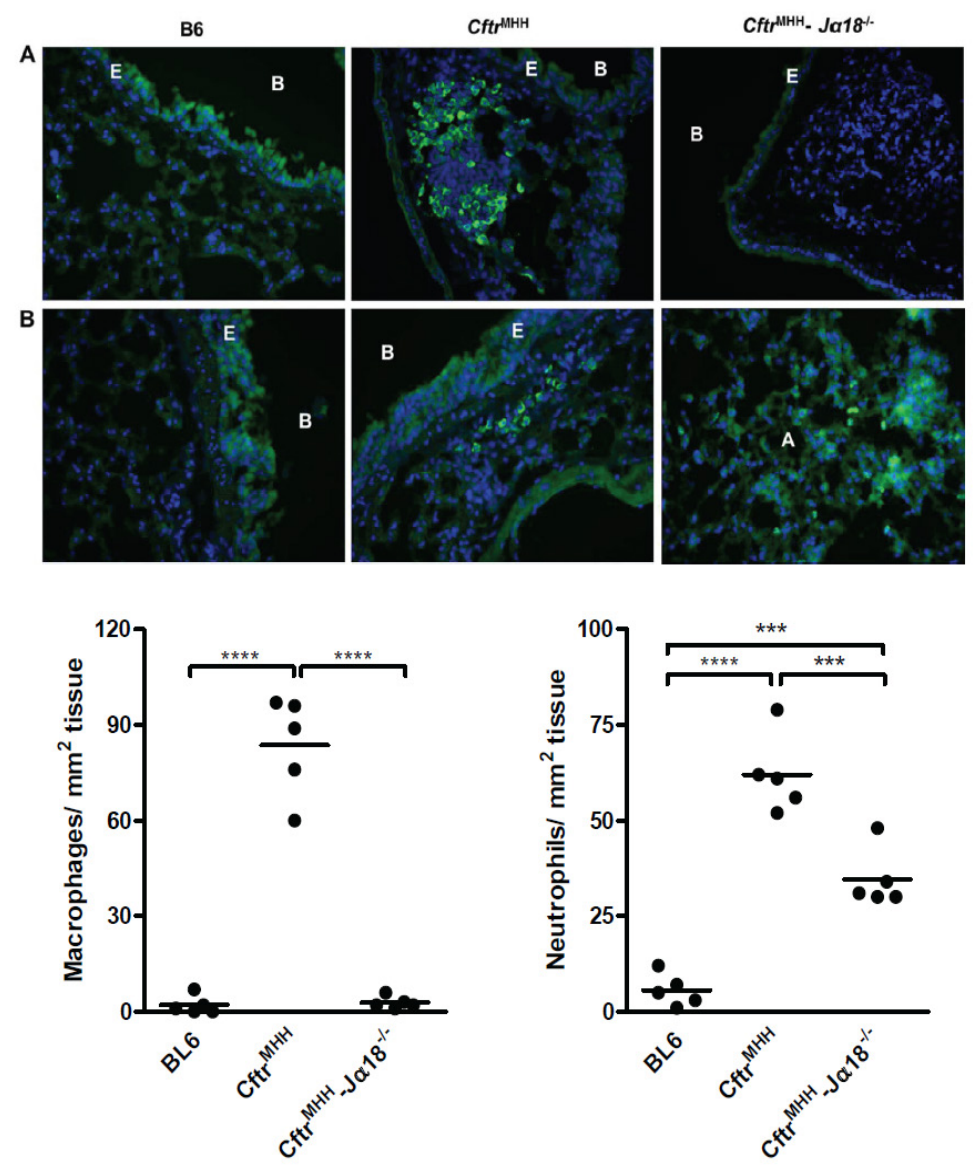
while the percentage of iNKT cells producing IL-17 were significantly increased in iNKT cells from lungs of $C f t r^{\mathrm{MHH}}$ mice (Fig. 5a). Likewise, in response to $\alpha$-GalCer stimulation, iNKT cells produced significantly less IFN- $\gamma$ and a trend towards increased IL-17 production compared to wild type mice was observed in $C \mathrm{ftr}^{\mathrm{MHH}}$ mouse lungs (Fig. 5a). Further analysis revealed that two different iNKT cell subpopulations are present in $C f \mathrm{fr}^{\mathrm{MHH}}$ mice, which produce either IL-17 or IFN- $\gamma$ (Fig. 5b). The large majority of IL-17 producing iNKT cells were positive for the transcription factor ROR- $\gamma$ t (Fig. 5b), which directs the differentiation of proinflammatory IL-17-positive T-lymphocytes, while negative for CD4 (Fig. 5b). This data establishes a predominantly IL-17 producing iNKT cell subpopulation in CF mice.

To investigate the significance of iNKT cell accumulation in the lung, we tested whether iNKT cells are involved in the accumulation of macrophages (Fig. 5c) and neutrophils (Fig. 5c) in lung tissues of $C \mathrm{ftr}^{\mathrm{MHH}}$ mice. Our results indicate an accumulation of these inflammatory cells in CF lungs, which was normalized by the absence of iNKT cells in $\mathrm{Cftr} \mathrm{MHH}_{-} J \alpha 18^{-/}$mice. Most importantly iNKT cells are completely responsible for the recruitment of macrophages into CF lungs, as reflected by the total lack of lung tissue macrophages in $\mathrm{Cftr}{ }^{\mathrm{MHH}}-\mathrm{J \alpha} 18^{-/-}$mice (Fig. 5c).

\section{Discussion}

Pleiotropic functions have been attributed to iNKT cells in human diseases $[29,30$, $38,39]$. Here, we demonstrate that iNKT cells suppress autoimmunity in mice with the hereditary disease cystic fibrosis, characterized by mutations in the Cftr gene, encoding an epithelial chloride channel [1]. Although the control of the auto-immune response is beneficial, the accumulation of iNKT cells results in detrimental recruitment of macrophages and neutrophils into the lung that mediate the chronic inflammation seen in CF patients.

This notion is based on the following lines of evidence: (a) In Cftr-deficient mice iNKT cells accumulate in tissue where Cftr-deficiency leads to increased cell death. (b) $C f t r{ }^{\mathrm{MH}}$ $J \alpha 18^{-/}$mice revealed elevated levels of anti-DNA antibodies compared to control mouse strains. The increase in IgG3 anti-DNA may indicate a role for the splenic marginal zone B (MZB) cell population, a B cell pool known to rapidly produce IgG3 and to contain autoreactive clones [40]. (c) Germinal center B cells were significantly up-regulated in lungs and spleens of $C f t r^{\mathrm{MHH}}-J \alpha 18^{\%}$ compared to $C f t r^{M H H}$ mice as evidenced by FACS and immunohistology. (d) Concentrations of BAFF, a key survival factor during B-cell maturation, were significantly up-regulated in serum samples of $\mathrm{Cftr}^{\mathrm{MHH}}-\mathrm{J} \alpha 18^{-/}$mice but not in the other mouse strains. This cytokine promotes survival of self-reactive B cell clones leading to autoimmunity, and elevated serum BAFF levels have been detected in some patients suffering from various autoimmune conditions [37]. (e) Prevention of autoantibody production by autoreactive B cells in CF is linked to iNKT cell accumulation in various organs affected by mutated Cftr: In two CF mouse strains iNKT cell levels increased rapidly after birth leading to sustained high cell levels. (f) Depletion of iNKT cells normalizes the number of macrophages and neutrophils in the lungs of CF mice. Cumulatively, these data demonstrate that iNKT cells prevent autoimmunity in CF mice, but trigger inflammation in the lung. Taken together this proposes a model where local cell death leads to the recruitment of iNKT cells that control the activation of autoreactive B cells as well as the recruitment of innate phagocytic cells. This could be favourably in the context of acute cell death, but during chronic exposure the chronically activated iNKT cells seem to promote inflammation.

The molecules that trigger iNKT cell accumulation remain elusive and may involve direct recognition of cell death antigens by iNKT cells or indirect recognition via CD1d expressing autoreactive B cells, other antigen-presenting cells such as plasmacytoid dentritic cells and macrophages, or T cells [29].

During chronic stimulation iNKT cells may differentiate into various subpopulations, which are characterized by specific cytokine expression. In $C f t^{\mathrm{MHH}}$ mice we detected a large proportion of IL-17 or IFN- $\gamma$ producing iNKT cells in lungs. The dominating IL-17 producing 
iNKT cell population has previously been linked to neutrophil recruitment [38]. Here we show that neutrophil influx into lung tissues of $C f t^{\mathrm{MHH}}$ mice is partially dependent on iNKT cells, while macrophage influx is completely dependent on iNKT cells. We hypothesize that the influx of professional phagocytes is needed to clear dead cells and debris. During chronic exposure to dead cells the iNKT triggered macrophage influx instead results in lung inflammation, which is a typical and important feature of CF.

Several studies in humans and mice suggest a chronic inflammation in the lung as one of the earliest changes in CF even prior to infection [5-7]. Chronic inflammation is considered to be one of the key changes in CF lungs and is critical for the development of lung disease and pulmonary infection. Studies on aborted fetuses [5] show an increase of inflammatory molecules such as un upregulation of ICAM-1 and cyclooxygenase 2 (COX-2) in bronchial epithelial cells of CF fetuses, increased Gro- $\gamma$-expression in CF-fetus' lungs, in particular in monocytes and endothelial cells and increased metalloprotease-1 (MMP) activity in the cartilage of these airways indicating an inflammation prior to exposure to infective pathogens. The study further shows that even in the lungs of these CF-fetuses NFKB is already activated as indicated by a nuclear translocation of the p65 subunit.

Here we provide a new concept how inflammation in the lung of CF patients is initiated, i.e. the accumulation of iNKT cells to control autoimmune disease, which is achieved for the price of chronic inflammation. Our data further suggest that reduction of ceramide will ultimately also reduce inflammation in the lung by normalising the high rate of cell death in bronchial epithelial cells. Such a reduction of ceramide might be achieved with the functional acid sphingomyelinase inhibitor amitriptyline, which reduces activity of the acid sphingomyelinase and normalizes ceramide levels and cell death of epithelial cells in $\mathrm{CF}$ mice [16]. Treatment with amitriptyline also normalized inflammation in the lungs of CF mice and, most importantly improved lung function in CF patients $[16,41]$ consistent with the present studies that used a genetic approach to target the acid sphingomyelinase in $\mathrm{CF}$ mice.

In summary, our results demonstrate a novel pathophysiological autoimmune mechanism, which links abnormal cell death in CF tissues to iNKT cell upregulation and lung inflammation in a mouse model of CF.

\section{Acknowledgments}

The authors want to thank Robert Hurwitz and Stephan Kaufmann (Max-Planck-Institute for Infection Biology, Berlin, Germany) for $\alpha$-GalCer-loaded CD1d tetramer and J $\alpha 18^{-/}$mice, the National Institute of Health (Bethesda, USA) for PBS57-loaded CD1d tetramer, Burkhard Tümmler (Medizinische Hochschule Hannover, Germany) for providing $C f t r^{\mathrm{MHH}}$ mice and Cornelia Grimmel for helping with FACS experiments. The study was supported by DFG grant GU 335/16-2.

\section{Disclosure Statement}

The authors declare to have no competing financial interests.

\section{References}

1 Meyers RA: Encyclopedia of Molecular Cell Biology and Molecular Medicine, ed 2nd Weinheim, Wiley-VCH Verlag, 2004.

-2 Rommens JM, Iannuzzi MC, Kerem B, Drumm M, Melmer G, Dean M Rozmahel R, Cole JL, Kennedy D, Hidaka N, Zsiga M, Buchwald M, Riordan JR, Tsui L-C, Collins FS: Identification of the cystic fibrosis gene: Chromosome walking and jumping. Science 1989;245:1059-1065. 
Siegmann et al: iNKT Cells in Cystic Fibrosis

3 Riordan JR, Rommens JM, Kerem B, Alon N, Rozmahel R, Grzelczak Z, Zielenski J, Lok S, Plavsic N, Chou JL, Drumm ML, Iannuzzi MC, Collins FS, Tsui L-C: Identification of the cystic fibrosis gene: Cloning and characterization of complementary DNA. Science 1989;245:1066-1073.

4 Kerem B, Rommens JM, Buchanan JA, Markiewicz D, Cox TK, Chakravarti A, Buchwald M, Tsui LC: Identification of the cystic fibrosis gene: Genetic analysis. Science 1989;245:1073-1080.

5 Armstrong DS, Hook SM, Jamsen KM, Nixon GM, Carzino R, Carlin JB, Robertson CF, Grimwood K: Lower airway inflammation in infants with cystic fibrosis detected by newborn screening. Pediatr Pulmonol 2005;40:500-510.

-6 Khan TZ, Wagener JS, Bost T, Martinez J, Accurso FJ, Riches DW: Early pulmonary inflammation in infants with cystic fibrosis. Am J Respir Crit Care Med 1995;151:1075-1082.

7 Verhaeghe C, Delbecque K, de Leval L, Oury C, Bours V: Early inflammation in the airways of a cystic fibrosis foetus. J Cyst Fibros 2007;6:304-308.

-8 Tabary O, Escotte S, Couetil JP, Hubert D, Dusser D, Puchelle E, Jacquot J: Relationship between IkappaBalpha deficiency, NFkappaB activity and interleukin-8 production in cf human airway epithelial cells. Pflugers Arch 2001;443:S40-44.

-9 Oceandy D, McMorran BJ, Smith SN, Schreiber R, Kunzelmann K, Alton EW, Hume DA, Wainwright BJ: Gene complementation of airway epithelium in the cystic fibrosis mouse is necessary and sufficient to correct the pathogen clearance and inflammatory abnormalities. Hum Mol Genet 2002;11:1059-1067.

10 Inoue H, Massion PP, Ueki IF, Grattan KM, Hara M, Dohrman AF, Chan B, Lausier JA, Golden JA, Nadel JA: Pseudomonas stimulates interleukin-8 mRNA expression selectively in airway epithelium, in gland ducts, and in recruited neutrophils. Am J Respir Cell Mol Biol 1994;11:651-663.

11 Bonfield TL, Konstan MW, Burfeind P, Panuska JR, Hilliard JB, Berger M: Normal bronchial epithelial cells constitutively produce the anti-inflammatory cytokine interleukin-10, which is downregulated in cystic fibrosis. Am J Respir Cell Mol Biol 1995;13:257-261.

$>12$ Tirouvanziam R, de Bentzmann S, Hubeau C, Hinnrasky J, Jacquot J, Peault B, Puchelle E: Inflammation and infection in naive human cystic fibrosis airway grafts. Am J Respir Cell Mol Biol 2000;23:121-127.

13 Venkatakrishnan A, Stecenko AA, King G, Blackwell TR, Brigham KL, Christman JW, Blackwell TS: Exaggerated activation of nuclear factor-kappab and altered IkappaB-beta processing in cystic fibrosis bronchial epithelial cells. Am J Respir Cell Mol Biol 2000;23:396-403.

14 Goldstein W, Doring G: Lysosomal enzymes from polymorphonuclear leukocytes and proteinase inhibitors in patients with cystic fibrosis. Am Rev Respir Dis 1986;134:49-56.

15 Stoltz DA, Meyerholz DK, Pezzulo AA, Ramachandran S, Rogan MP, Davis GJ, Hanfland RA, Wohlford-Lenane C, Dohrn CL, Bartlett JA, Nelson GAt, Chang EH, Taft PJ, Ludwig PS, Estin M, Hornick EE, Launspach JL, Samuel M, Rokhlina T, Karp PH, Ostedgaard LS, Uc A, Starner TD, Horswill AR, Brogden KA, Prather RS, Richter SS, Shilyansky J, McCray PB Jr, Zabner J, Welsh MJ: Cystic fibrosis pigs develop lung disease and exhibit defective bacterial eradication at birth. Sci Transl Med 2010;2:29ra31.

-16 Teichgraber V, Ulrich M, Endlich N, Riethmuller J, Wilker B, De Oliveira-Munding CC, van Heeckeren AM, Barr ML, von Kurthy G, Schmid KW, Weller M, Tummler B, Lang F, Grassme H, Doring G, Gulbins E: Ceramide accumulation mediates inflammation, cell death and infection susceptibility in cystic fibrosis. Nat Med 2008;14:382-391.

17 Brodlie M, McKean MC, Johnson GE, Gray J, Fisher AJ, Corris PA, Lordan JL, Ward C: Ceramide is increased in the lower airway epithelium of people with advanced cystic fibrosis lung disease. Am J Respir Crit Care Med 2010;182:369-375.

18 Bodas M, Min T, Vij N: Critical role of Cftr-dependent lipid rafts in cigarette smoke-induced lung epithelial injury. Am J Physiol Lung Cell Mol Physiol 2011;300:L811-820.

19 Ulrich M, Worlitzsch D, Viglio S, Siegmann N, Iadarola P, Shute JK, Geiser M, Pier GB, Friedel G, Barr ML, Schuster A, Meyer KC, Ratjen F, Bjarnsholt T, Gulbins E, Doring G: Alveolar inflammation in cystic fibrosis. J Cyst Fibros 2010;9:217-227.

20 Becker KA, Riethmuller J, Luth A, Doring G, Kleuser B, Gulbins E: Acid sphingomyelinase inhibitors normalize pulmonary ceramide and inflammation in cystic fibrosis. Am J Respir Cell Mol Biol 2010;42:716724.

21 Becker KA, Tummler B, Gulbins E, Grassme H: Accumulation of ceramide in the trachea and intestine of cystic fibrosis mice causes inflammation and cell death. Biochem Biophys Res Commun 2010;403:368374. 
22 Dbaibo GS, Hannun YA: Signal transduction and the regulation of apoptosis: Roles of ceramide. Apoptosis 1998;3:317-334.

23 Uhlig S, Gulbins E: Sphingolipids in the lungs. Am J Respir Crit Care Med 2008;178:1100-1114.

24 Gulbins E, Kolesnick R: Raft ceramide in molecular medicine. Oncogene 2003;22:7070-7077.

25 Maiuri L, Raia V, De Marco G, Coletta S, de Ritis G, Londei M, Auricchio S: DNA fragmentation is a feature of cystic fibrosis epithelial cells: A disease with inappropriate apoptosis? FEBS Lett 1997;408:225-231.

26 Durieu I, Amsellem C, Paulin C, Chambe MT, Bienvenu J, Bellon G, Pacheco Y: Fas and fas ligand expression in cystic fibrosis airway epithelium. Thorax 1999;54:1093-1098.

27 Utz PJ, Gensler TJ, Anderson P: Death, autoantigen modifications, and tolerance. Arthritis Res 2000;2:101114.

-28 Gaipl US, Kuhn A, Sheriff A, Munoz LE, Franz S, Voll RE, Kalden JR, Herrmann M: Clearance of apoptotic cells in human SLE. Curr Dir Autoimmun 2006;9:173-187.

29 Wermeling F, Lind SM, Jordo ED, Cardell SL, Karlsson MC: Invariant NKT cells limit activation of autoreactive CD1d-positive B cells. J Exp Med 2010;207:943-952.

-30 Kronenberg M: Toward an understanding of NKT cell biology: Progress and paradoxes. Annu Rev Immunol 2005;23:877-900.

-31 Cui J, Shin T, Kawano T, Sato H, Kondo E, Toura I, Kaneko Y, Koseki H, Kanno M, Taniguchi M: Requirement for valpha14 NKT cells in IL-12-mediated rejection of tumors. Science 1997;278:1623-1626.

-32 Kojo S, Adachi Y, Keino H, Taniguchi M, Sumida T: Dysfunction of T cell receptor $\alpha v 24 \alpha j 18+, \beta v 11+$ doublenegative regulatory natural killer T cells in autoimmune diseases. Arthritis Rheum 2001;44:1127-1138.

-33 Dorin JR, Dickinson P, Alton EW, Smith SN, Geddes DM, Stevenson BJ, Kimber WL, Fleming S, Clarke AR, Hooper ML, et al.: Cystic fibrosis in the mouse by targeted insertional mutagenesis. Nature 1992;359:211215.

-34 Charizopoulou N, Jansen S, Dorsch M, Stanke F, Dorin JR, Hedrich HJ, Tummler B: Instability of the insertional mutation in Cftrtgh(neoim)hgu cystic fibrosis mouse model. BMC Genet 2004;5:6.

35 Yang Y, Raper SE, Cohn JA, Engelhardt JF, Wilson JM: An approach for treating the hepatobiliary disease of cystic fibrosis by somatic gene transfer. Proc Natl Acad Sci U S A 1993;90:4601-4605.

-36 Schiotz PO, Egeskjold EM, Hoiby N, Permin H: Autoantibodies in serum and sputum from patients with cystic fibrosis. Acta Pathol Microbiol Scand C 1979;87:319-324.

37 Mackay F, Schneider P: Cracking the Baff code. Nat Rev Immunol 2009;9:491-502.

38 Bendelac A, Rivera MN, Park SH, Roark JH: Mouse CD1-specific NK1 T cells: Development, specificity, and function. Annu Rev Immunol 1997; 15:535-562.

39 Michel ML, Keller AC, Paget C, Fujio M, Trottein F, Savage PB, Wong CH, Schneider E, Dy M, Leite-de-Moraes MC: Identification of an IL-17-producing NK1.1(neg) iNKT cell population involved in airway neutrophilia. J Exp Med 2007;204:995-1001.

40 Enzler T, Bonizzi G, Silverman GJ, Otero DC, Widhopf GF, Anzelon-Mills A, Rickert RC, Karin M: Alternative and classical NF-kappa B signaling retain autoreactive B cells in the splenic marginal zone and result in lupus-like disease. Immunity 2006;25:403-415.

41 Nährlich L, Mainz JG, Adams C, Engel C, Herrmann G, Icheva V, Lauer J, Deppisch C, Wirth A, Unger K, Graepler-Mainka U, Hector A, Heyder S, Stern M, Döring G, Gulbins E, Riethmüller J: Therapy of CF-patients with amitriptyline and placebo - a randomised, double-blind, placebo-controlled phase IIb multicenter, cohort study. Cell Physiol Biochem 2013;31:505-512. 